\title{
Nieniszczące badania płyt włóknisto-cementowych z wykorzystaniem emisji akustycznej
}

\author{
Non-destructive testing of fiber-cement board \\ using acoustic emission method
}

\section{Streszczenie}

W artykule przedstawiono propozycję zastosowania do badania płyt włóknisto-cementowych nieniszczącą metodę emisji akustycznej. Badaniom poddano łącznie 4 serie materiałów włóknisto-cementowych oznaczonych literami A, AW, B i BW. Dwie serie A i B stanowiły losowo wybrane płyty dostępne na rynku budowlanym, które następnie poddano procesowi wypalenia w temperaturze $230{ }^{\circ} \mathrm{C}$ - seria AW i BW. Uzyskano ciekawe rezultaty badań, które pozwoliły odróżnić proces niszczenia zawartych w materiale włókien od procesu niszczenia samej matrycy.

Słowa kluczowe: badania nieniszczące; płyty włóknisto-cementowe; emisja akustyczna

\section{Abstract}

This article show proposition of using acoustic emission as a non-destructive method for testing fiber-cement board. For testing was used four series of fiber-cement board marked A, AW, B, BW. Two series A and B was randomly selected from available board in market, which then were subjected to burn-out at $230{ }^{\circ} \mathrm{C}$ - a series of AW and BW. Obtained interesting results of research which helps describe destruction process of fibers and cement matrix.

Keywords: non-destructive testing; fiber-cement board; acoustic emission

\section{Wstęp}

Płyty włóknisto-cementowe najczęściej stosowane są jako okładziny elewacji wentylowanych montowane na podkonstrukcji $[1,2]$. Widok przykładowych elewacji z wykorzystaniem takich płyt pokazano na rysunku 1. Okładziny elewacyjne narażone są na duże obciążenia w wyniku parcia i ssania wiatru, ale również na bardzo zmienne warunki klimatyczne. Stąd też materiał ten musi być dokładnie sprawdzony przed wbudowaniem, a przede wszystkim w trakcie jego wytwarzania. Istotnym jest wówczas sprawdzenie składu mieszanki oraz ilości i sposobu rozłożenia włókien celulozowych i PVA. Nieprawidłowo rozłożone włókna nie tworzą przestrzennej siatki zbrojeniowej, co sprawia, że płyta nie posiada wymaganych parametrów wytrzymałościowych i przede wszystkim trwałości.

Kontrola prawidłowości rozłożenia włókien wewnątrz płyty jest bardzo trudna. Jedną z metod kontroli płyt jest normowe badanie wytrzymałości na zginanie dla wybranych partii, na podstawie pobranych z nich próbek o wymiarach $250 \times 250 \mathrm{~mm}$ [3]. Jest to metoda zgrubna i obarczona dużym błędem, a duża zmienność w wytrzymałości tych próbek świadczyć może zarówno o nierównomiernym rozłożeniu w nich włókien, ale także o niejednorodności samej matrycy cementowej. Potrzebna byłaby zatem dokładniejsza metoda, która pozwoliłaby na obserwację, jak „zachowuje się" płyta włóknisto-cementowa z włóknami z różną ich zawartością lub wręcz w przypadku ich braku. W literaturze opisano

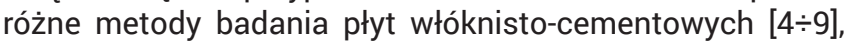
ale zauważa się brak metody, która pozwoliłaby odróżnić proces niszczenia zawartych w materiale włókien od procesu niszczenia samej matrycy cementowej i tym samym szacować zawartość włókien. Autorzy niniejszej pracy zaproponowali zastosowanie do takiej obserwacji metodę emisji akustycznej, którą wykorzystali do badania wybranych płyt dostępnych na rynku budowlanym.

\section{Opis badań}

Badaniom poddano 4 serie materiałów włóknisto-cementowych oznaczonych literami A, AW, B i BW, których

Dr inż. Tomasz Gorzelańczyk, dr hab. inż. Krzysztof Schabowicz, mgr inż. Mateusz Szymków - Politechnika Wrocławska. Autor korespondencyjny/Corresponding author. k.schabowicz@pwr.edu.pl 

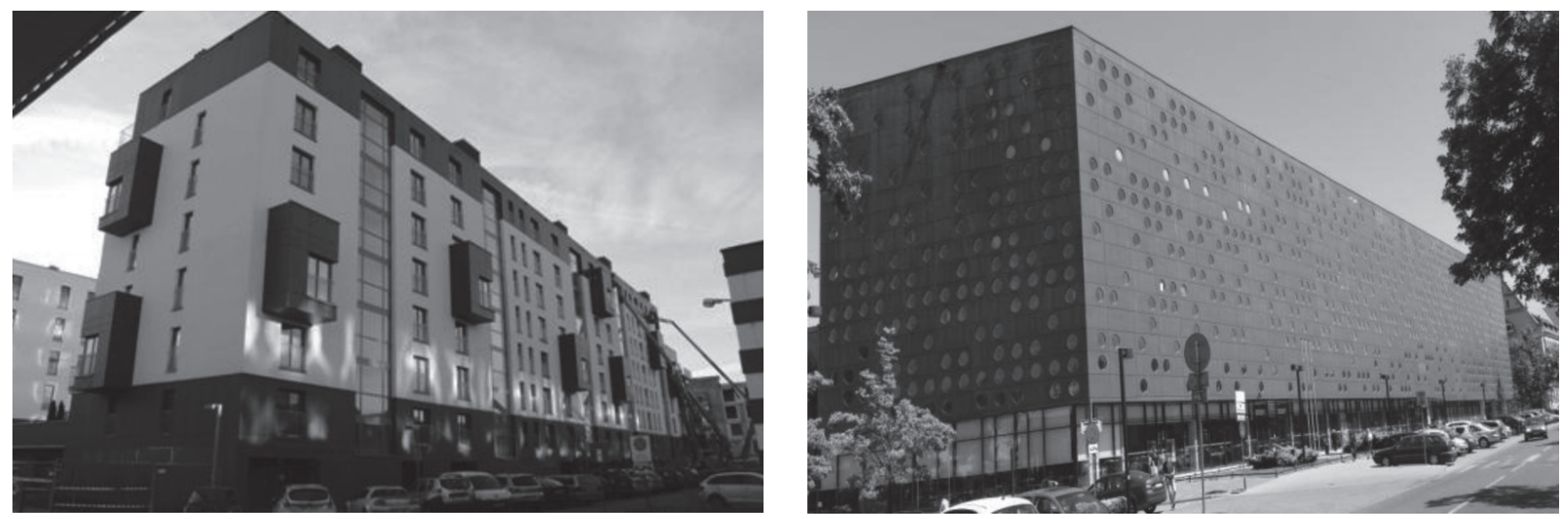

Rys. 1. Przykładowe elewacje wentylowane z wykorzystaniem płyt włóknisto-cementowych na budynku mieszkalnym i użyteczności publicznej

Fig. 1. Ventilated façade with fiber-cement boards, examples of implementation housing and civil building

Tablica I. Podstawowe parametry badanych próbek płyt włóknisto-cementowych

Table I. Basic parameters of the tested fiber-cement boards samples

\begin{tabular}{|c|c|c|c|c|}
\hline L.p. & 1 & 2 & 3 & 4 \\
\hline Oznaczenie próbki & $A$ & AW & B & BW \\
\hline Szerokość próbki [mm] & 20 & 20 & 20 & 20 \\
\hline Grubość płyty [mm] & 8 & 8 & 8 & 8 \\
\hline Rodzaj płyty & $\begin{array}{c}\text { włóknisto- } \\
\text {-cementowa } \\
\text { barwiona w masie }\end{array}$ & $\begin{array}{c}\text { włóknisto- } \\
\text {-cementowa } \\
\text { barwiona w masie }\end{array}$ & $\begin{array}{l}\text { włóknisto- } \\
\text {-cementowa } \\
\text { malowana }\end{array}$ & $\begin{array}{l}\text { włóknisto- } \\
\text {-cementowa } \\
\text { malowana }\end{array}$ \\
\hline $\begin{array}{c}\text { Obróbka cieplna } \\
\text { w temperaturze } 230^{\circ} \mathrm{C}\end{array}$ & nie & tak & nie & tak \\
\hline $\begin{array}{l}\text { Wytrzymałość na zginanie } \\
\text { badanych próbek [MPa] wyzna- } \\
\text { czona wg wzoru podanego } \\
\text { w p. } 7.3 .2 .4 .1 \text { normy [3] }\end{array}$ & 32,18 & 13,20 & 36,40 & 7,18 \\
\hline Gęstość objętościowa [kg/m³] & 1550 & nie określano & 1600 & nie określano \\
\hline Widok płyty & & nem & & \\
\hline
\end{tabular}

podstawowe parametry zamieszczono w tablicy I. Badane próbki zostały wycięte $z$ większych fragmentów płyt włóknisto-cementowych i miały wymiary 8x20x100 mm. Z każdej serii przebadano po 6 próbek. Próbki oznaczone przez AW i BW różniły się od próbek oznaczonych literami A i B obróbką cieplną. Obróbki cieplnej tych próbek dokonano w piecu laboratoryjnym w temperaturze $230{ }^{\circ} \mathrm{C}$ przez ok. 2 godziny. Obróbka cieplna miała na celu zniszczenie (wypalenie) włókien celulozowych oraz włókien PVA znajdujących się w składzie badanych płyt.

Badania procesu niszczenia płyt włóknisto-cementowych podczas trójpunktowego zginania, przeprowadzono z wykorzystaniem mikroprasy Pascal $(3 \mathrm{kN})$ oraz jednoczujnikowego zestawu do badań metodą emisji akustycznej. Widok zestawu aparatury do badań metodą emisji akustycznej pokazano przykładowo na rysunku 2.

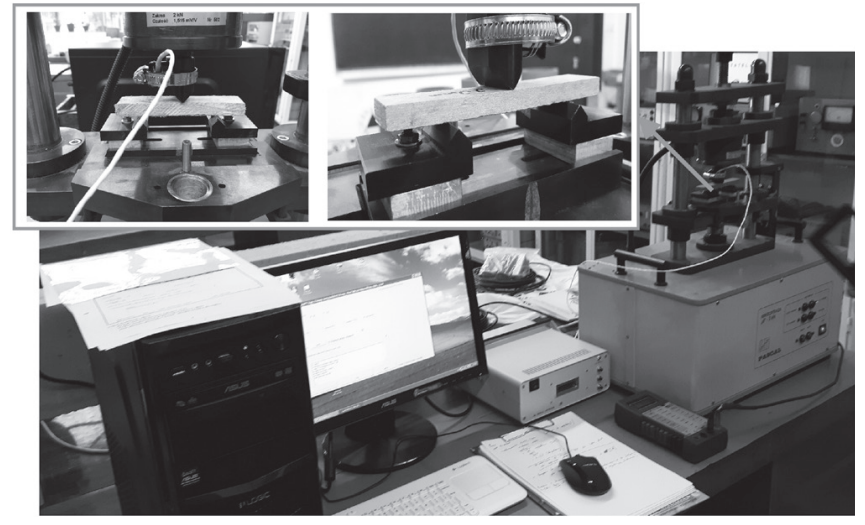

Rys. 2. Zestaw aparatury do badań metodą emisji akustycznej Fig. 2. Test equipment of acoustic emission method 
W trakcie trójpunktowego zginania próbek włóknistocementowych rejestrowanymi deskryptorami emisji akustycznej w funkcji czasu były liczba zliczeń EA oraz energia zdarzeń EA. Proces zginania był prowadzony ze stałym przyrostem przemieszczenia trawersy maszyny wytrzymałościowej wynoszącym 0,1 mm/m.

\section{Wyniki badań $\mathrm{i}$ ich analiza}

Na rysunkach $3 \div 6$ pokazano przykładowy zapis liczby zliczeń emisji akustycznej w funkcji czasu oraz zapis energii zdarzeń emisji akustycznej w funkcji czasu wraz z naniesionym wykresem przyrostu siły, odpowiednio dla badanych serii próbek A, AW, B i BW.

Na podstawie analizy rysunków 3 i 4 widać istotną różnicę w procesie niszczenia badanych próbek serii A i AW. Jak widać z tych rysunków, obróbka cieplna istotnie wpływa na charakter zapisu liczby zliczeń EA i energię zdarzeń EA. W przypadku próbek serii A obserwuje się niewielką aktywność akustyczną w prawie całym procesie. Dopiero tuż przed momentem zniszczenia próbki (przy poziomie 98\% siły niszczącej) następuje bardzo znaczący wzrost zarówno liczby zliczeń jak i energii zdarzeń emisji akustycznej. W przypadku próbek serii AW nie obserwuje się żadnej aktywności akustycznej do momentu zniszczenia. W momencie zniszczenia występuje jeden gwałtowny wzrost rejestrowanych deskryptorów. Jeżeli chodzi o próbki serii B i BW, to analizując rysunki 5 i 6 widać, że proces ich niszczenia jest analogiczny do próbek serii A i AW. Z tym, że w przypadku próbek serii B (rys. 5a) widać większą aktywność akustyczną i wyższą wartość zarejestrowanej energii zdarzeń emisji akustycznej znacznie wcześniej przed osiągnięciem zniszczenia próbki, bo już przy poziomie około $88 \%$ siły niszczącej. Również zarejestrowana wartość energii zdarzeń EA jest znacznie wyższa niż w przypadku próbek serii A. Zdaniem autorów różnica ta może świadczyć o większej ilości włókien zarówno celulozowych jak również PVA w składzie płyt włóknisto-cementowych serii B lub też ich wyższej wytrzymałości. Fakt ten może mieć również związek ze sposobem rozmieszczenia włókien w strukturze badanego materiału. Z kolei wykorzystywane w pracy próbki serii AW i BW (po obróbce cieplnej) miały na celu pomóc odróżnić proces niszczenia zawartych w materiale włókien od procesu niszczenia samej matrycy. Autorzy mają pewne sugestie dotyczące tego faktu, jednak zagadnienie to okazuje się być bardziej złożone, stąd też wymaga jeszcze przeprowadzenia dodatkowych analiz, których rezultaty na pewno będą przedmiotem kolejnych publikacji.
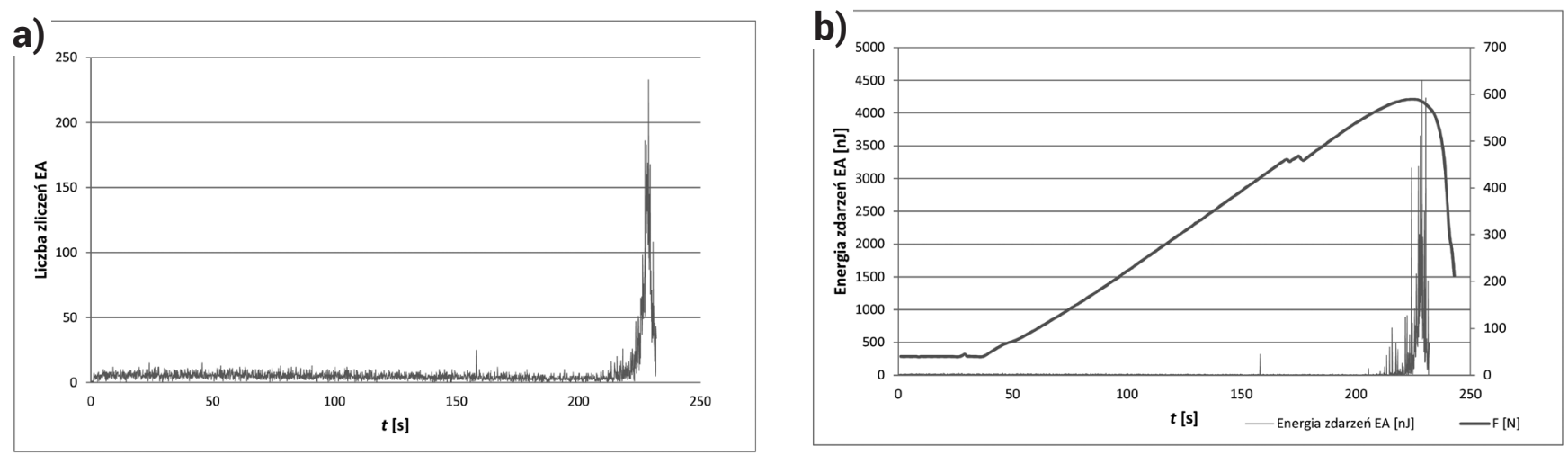

Rys. 3. Zapis dla próbki serii A: a) liczby zliczeń emisji akustycznej, b) energii zdarzeń emisji akustycznej wraz z naniesionym wykresem przyrostu siły

Fig. 3. Recording for the sample series A: a) the number of acoustic emission counts, b) the energy of acoustic emission events and graph of strength increase
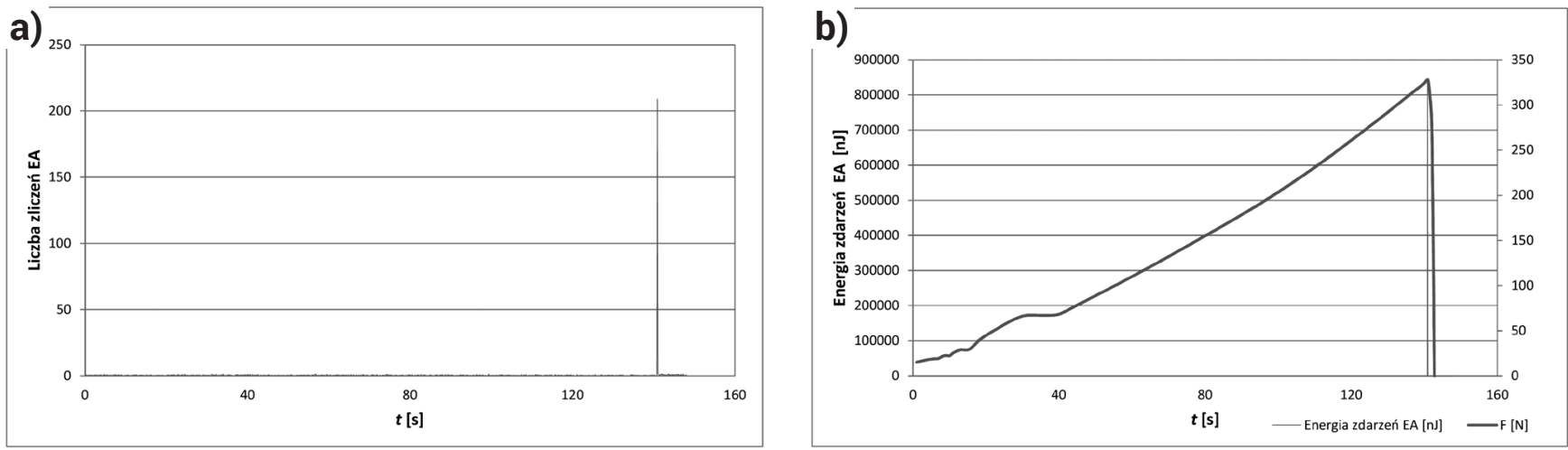

Rys. 4. Zapis dla próbki serii AW: a) liczby zliczeń emisji akustycznej, b) energii zdarzeń emisji akustycznej wraz z naniesionym wykresem przyrostu siły

Fig. 4. Recording for the sample series AW: a) the number of acoustic emission counts, b) the energy of acoustic emission events and graph of strength increase 
a)

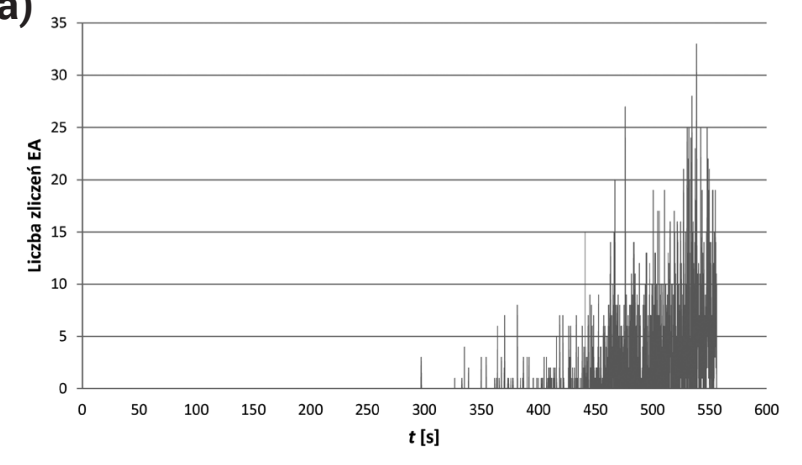

b)

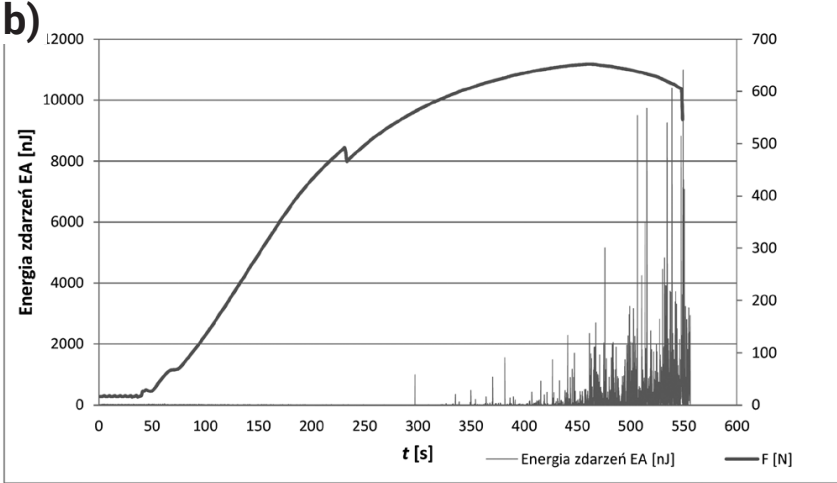

Rys. 5. Zapis dla próbki serii B: a) liczby zliczeń emisji akustycznej, b) energii zdarzeń emisji akustycznej wraz z naniesionym wykresem przyrostu siły

Fig. 5. Recording for the sample series B: a) the number of acoustic emission counts, b) the energy of acoustic emission events and graph of strength increase
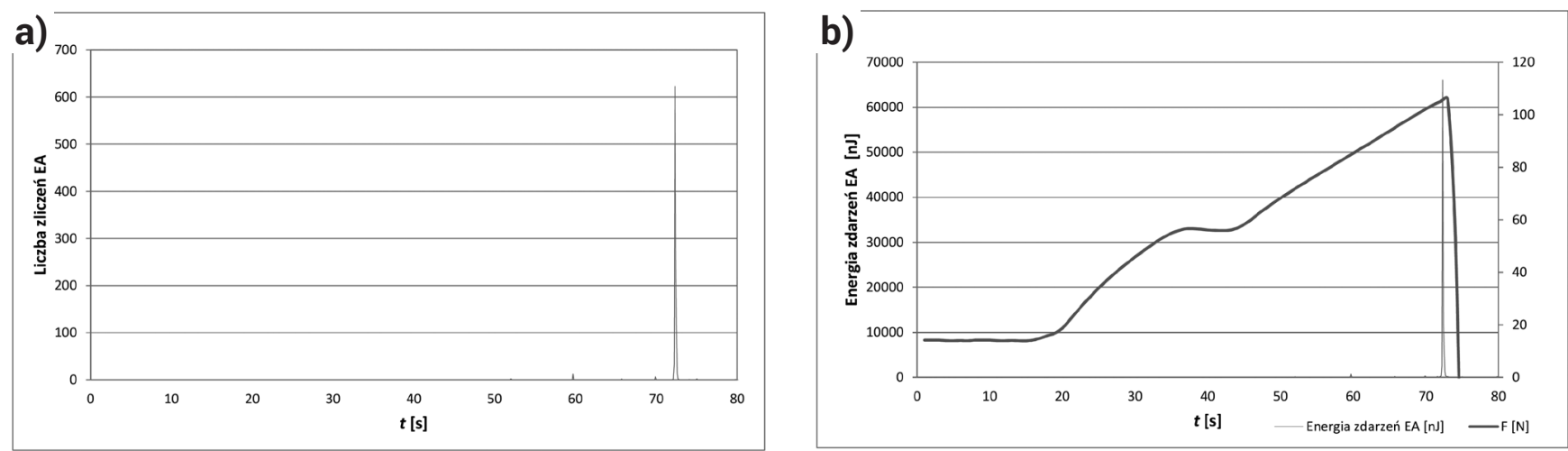

Rys. 6. Zapis dla próbki serii BW: a) liczby zliczeń emisji akustycznej, b) energii zdarzeń emisji akustycznej wraz z naniesionym wykresem przyrostu siły

Fig. 6. Recording for the sample series BW: a) the number of acoustic emission counts, b) the energy of acoustic emission events and graph of strength increase

\section{Podsumowanie}

W artykule przedstawiono propozycję zastosowania do badania płyt włóknisto-cementowych metodę emisji akustycznej. Badaniom poddano łącznie 4 serie materiałów włóknisto-cementowych oznaczonych literami A, AW, B i BW. Dwie serie A i B stanowiły losowo wybrane płyty dostępne na rynku budowlanym, które następnie poddano procesowi obróbki cieplnej w temperaturze $230{ }^{\circ} \mathrm{C}$ - seria AW i BW. Uzyskano ciekawe rezultaty badań, które pozwoliły odróżnić proces niszczenia zawartych w materiale włókien od procesu niszczenia samej matrycy.

Ponieważ autorzy nie spotkali się dotychczas z podobnymi badaniami w literaturze, należy sądzić, że znajomość przedmiotowego procesu niszczenia oraz opracowanie własnej metodyki badań, pozwoli w przyszłości oceniać jakość badanych materiałów włóknisto-cementowych zarówno pod kątem jakości samej matrycy cementowej, ale przede wszystkim ilości, wytrzymałości i sposobu rozmieszczenia włókien w badanym materiale.

\section{Literatura}

[1] Informacje ze strony internetowej: http://www.euronit.de/

[2] Informacje ze strony internetowej: http://www.cembrit.com/

[3] PN-EN 12467:2013-03E - Płyty płaskie włóknisto-cementowe. Charakterystyka wyrobu i metody badań.

[4] R. Drelich, T. Gorzelańczyk, M. Pakuła, K. Schabowicz: Automated Control of Cellulose Fibre Cement Boards with a Non-Contact Ultrasound Scanner, Automation in Construction, 57, s. 55-63, 2015.

[5] T. Gorzelańczyk, K. Schabowicz: Non-Destructive Testing of Moisture in Cellulose Fiber Cement Boards, 11th European Conference on Non-Destructive Testing (ECNDT), Prague, 2014

[6] T. Gorzelańczyk, K. Schabowicz: Badania płyt włóknisto-cementowych zawierających materiały $\mathrm{z}$ recyklingu, Materiały Budowlane, $\mathrm{nr}$ 10, s. $27-29,2015$.
[7] T. Gorzelańczyk, K. Schabowicz: Rewitalizacja elewacji budynków z zastosowaniem płyt włóknisto-cementowych, Materiały Budowlane, $\mathrm{nr} 11$, s. $163-165,2015$.

[8] Z. Ranachowski, D. Jóźwiak-Niedźwiedzka, A.M. Brandt, T. Dębowski: Application of Acoustic Emission Method to Determine Critical Stress in Fibre Reinforced Mortar Beams, Archives of Acoustics, Vol.37, Nr 3, s. 261-268, 2012.

[9] K. Schabowicz, Z. Ranachowski, D. Jóźwiak-Niedźwiedzka, Ł. Radzik, Jr. S. Kudela, T. Dvorak: Application of X-ray microtomography to quality assessment of fibre cement boards, Construction and Building Materials, Vol. 110, s. 182-188, 2016.

[10] Tomasz Gorzelańczyk, Krzysztof Schabowicz: Nieniszczące badania wilgotności płyt włóknisto-cementowych metodą dielektryczną, Przegląd Spawalnictwa, Vol 86, No 11 (2014). 